\title{
Evaluation of Internal Control over Financial Reporting Designed on Tax Receivable Management: A Case Study on Tax Receivable Management Cycle at the Directorate General of Taxes
}

\author{
Asrulsani Muhamad ${ }^{1 *}$, Trisacti Wahyuni ${ }^{1}$ \\ ${ }^{1}$ Faculty of Economics and Business, Universitas Indonesia, Depok 16424, Indonesia \\ *asrulsani.m@gmail.com
}

\begin{abstract}
The purposes of this research are to assess the adequacy of the control design and to propose improvements to Internal Control over Financial Reporting that can be utilized by the Directorate General of Taxes as a manager of tax receivable in support of transparency and accountability of the government financial statements. This research used a qualitative method with a case study approach to the Directorate General of Taxes as the unit analysis. The results show that the control design in the recording of tax receivable has not been fully effective. There are risks identified and gaps in the control which could lead to potential misstatements, whether overstatement or understatement of tax receivable. Weaknesses are also found in the tax receivable accounting policies that do not fully comply with the accrual principle, the issuance of Tax Letter and Tax Bill that still could be done manually, and the absence of data exchange portal between the Directorate General of Taxes and the Tax Court. To improve the condition, the researcher suggested the Directorate General of Taxes to revise the accounting policy of tax receivable, using the application from the determination to the settlement of receivable, and to develop the application with the Tax Court as the data exchange portal.
\end{abstract}

Keywords: Internal Control over Financial Reporting; Account Receivable Accounting Policies; Internal Control; Tax Receivable; Tax Information System.

\section{INTRODUCTION}

The Law number 1 of 2004 concerning Country Treasury stipulates that the President as a government leader should manage and carry out the internal control system in a government institution. The internal control is expected to be applied comprehensively so that it can improve the performance, transparency, and accountability of the country's financial management. To execute the instruction, the government publishes Government Regulation number 60 of 2008 concerning Government Internal Control System.

To increase the accountability of the country's financial management through financial reporting, the government has to arrange an internal control related to country's financial report compiling. By referring to those issues, a control mechanism related to the tax receivable documentation in Directorate General of Taxes (DGT) is highly required thus the right presentation of financial report especially account receivable of tax can be convinced. Nowdays, the management of tax receivable is supported with information system called Sistem Informasi Direktorat Jendral Pajak (SIDJP) or Directorate General of Taxes Information System.

IPSAS 23 concerning Revenue from Non-Exchange Transaction (taxes and transfer) paragraph 29 states that the entity will recognize an asset arising from a non-exchange transaction when it gains control of resources that meets the definition of an asset and the recognition criteria ${ }^{1}$. An entity has to recognize assets during the occurrence of taxable event and meet the asset recognition criteria ${ }^{1}$.

Government's Accounting Conceptual Framework paragraph 91 related to asset recognition, states that "in line with application of accrual basis, asset in the form of receivable or prepaid expenses is recognized when the right of claim for getting cash inflows or other economic benefits from the other entity has been or still fulfilled, and the claim value can be measured or estimated"2. Government Accounting Standard 01 concerning Presentation of Financial Reporting also states that assets are recognized when the potential economic benefits in the future can be obtained by the government and the economic benefits have value or costs that can be measured reliably ${ }^{3}$. Tax receivable is a state receivable from the country's revenue that occurs based on charges. Technical Bulletin Number 16 concerning Accounting of Accounts Receivable Based on Accruals explains that to be recognized as receivable, it has to fulfill these criteria: (1) issued letter of decision has been issued and/or; (2) collection letter has been issued and that the billing has been done ${ }^{4}$. 
From the background of study stated above, the researchers formulate the problems below:

1. How is the adequacy of ICFR design of the management of tax receivable cycle to mitigate risks?

2. How to design an effective ICFR of the management tax receivable to fulfill transparency and accountability principle in financial reporting?

To further overcome the problems described above, this research will focus on the problems related to the assessment of ICFR effectiveness on the tax receivable management process which is executed by the DGT, the Ministry of Finance. The purposes of this research are to assess the adequacy of the control design and to give ICFR improvement suggestion which can be used by the DGT as the executor of tax receivable in order to support transparency and accountability of the government's financial statement.

\section{LITERATURE REVIEW}

The main objective of internal control according to COSO is to boost the effectiveness and efficiency of operation, the reliability of financial statement, and the compliance with law and regulation ${ }^{5}$. An organization or a process has a good internal control if (1) completing the mission ethically; (2) producing accurate and reliable data; (3) complying with the law and regulation; (4) using economic resources with efficient manner, and (5) safeguarding the assets properly ${ }^{6}$.

Internal control is considered effective if the internal control system built is able to give reasonable assurance that the organization's goal can be reached ${ }^{5}$. The effective internal control system is also able to reduce occurrence of risk of failure to achieve the first, second or third goals ${ }^{5}$. To make an effective internal control, it is suggested that: (1) each component of the internal control and the relevant principle obviously exist and work together, and (2) all 5 components of internal control work together and are integrated to decrease the level of risk of failure to achieve the organization's goal.

An effective internal control only cannot assure the achievement of the organization's goal. The internal control cannot wholly prevent the occurrence of assessment error, inappropriate decision-making, or incident out of organization which can cause organization's failure in achieving operational goals. Therefore, the term of internal control means it gives reasonable assurance, not absolute one. The Center for Audit Quality (CAQ) in a publication entitled "The Guide to Internal Control over Financial Reporting" defines ICFR as a control specially designed in order to manage risks related to financial reporting to obtain reasonable assurance that the financial report can be trusted and has been presented based on accounting principles. ${ }^{7}$. Those stated as the key components in ICFR are controlling activities which cover 3 concepts; they are segregation of duty, preventive control, and detective control ${ }^{7}$.

The definition of tax based on Law Number 16 of 2009 concerning General Requirements and Tax Procedure is a compulsory contribution to a country that is owed by a person or institution and it is coercive in nature based on constitution, by not getting the wards directly and used for the country's needs as much as possible for public prosperity ${ }^{8}$. Tax receivable in this research is as defined in the Ministry of Finance Regulation number 219/2013 concerning Accounting Policy of Central Government. According to the regulation, tax receivable is a receivable that occurs as a result of income tax in the constitution regulation in taxations and constitution regulation in customs, and has not been paid off until the end of the financial reporting period.

\section{RESEARCH METHOD}

The method of this research was a qualitative descriptive method using a case study approach as stated by Yin as quoted by Wahyuni " $a$ case study is the investigation of a contemporary, empirical phenomenon within its real life context; when the boundaries between a phenomenon and its context are not clearly evident; and in which multiple sources of evidence are used"6. This research was supported with primary data (in depth interview) using unstructured interview approach to follow the focus of the interviewees. The primary data was obtained from in depth interview toward employees in the DGT and internal auditors of the Ministry of Finance. The sampling method was done by purposive sampling in accordance with the level of roles and responsibilities of a person / individual to be sampled. As a unit analysis in this research, DGTs is one of the Echelon I units within the Ministry of Finance that has the duties of organizing the formulation and implementation of tax policy in accordance with the law and regulation.

The researchers analyzed the interview result by reading all interview result and then composing it to the meaningful fragments. Then, those fragments were labeled so that they could help the researcher perform the analysis about the relation on each label. Then, the researchers conducted the data analysis using gap analysis for finding out the expectation and the condition of controlling nowadays. To obtain the validity of the research result, the researcher asked for feedback ${ }^{6}$ toward research objects to ensure that the information is accurate and complete. 


\section{RESULTS AND DISCUSSION}

Tax Receivable Accounting Policy

DGT records tax receivable guided with PER-08/PJ/2009 concerning Guidelines of Tax Receivable Accounting $^{9}$ that governs the tax receivable accounting policy. The recognition of tax receivable currently is described in figure 1.

The tax receivable recognition causes some problems as follows:

1. The recognition of tax receivable is not completely done on the time of taxable event. In this case, Tax Bill and Tax Letter is issued corresponding to point 18 Law number 16 of 2009 concerning General Taxes.

2. When a taxpayer does not propose objection/appeal after the deadline is declared inkracht (permanent legal force), the bill amount which is not agreed by the tax payer, will be recognized as tax receivable by DGT. The recognition of tax receivable is not supported by legal document as the basis recording, because the overdue of the submission of legal action does not produce any document.

3. Tax receivable accounting is influenced by the rule of tax collecting. Based on constitution, the existence of legal action proposed by tax payers will cause billing suspension.

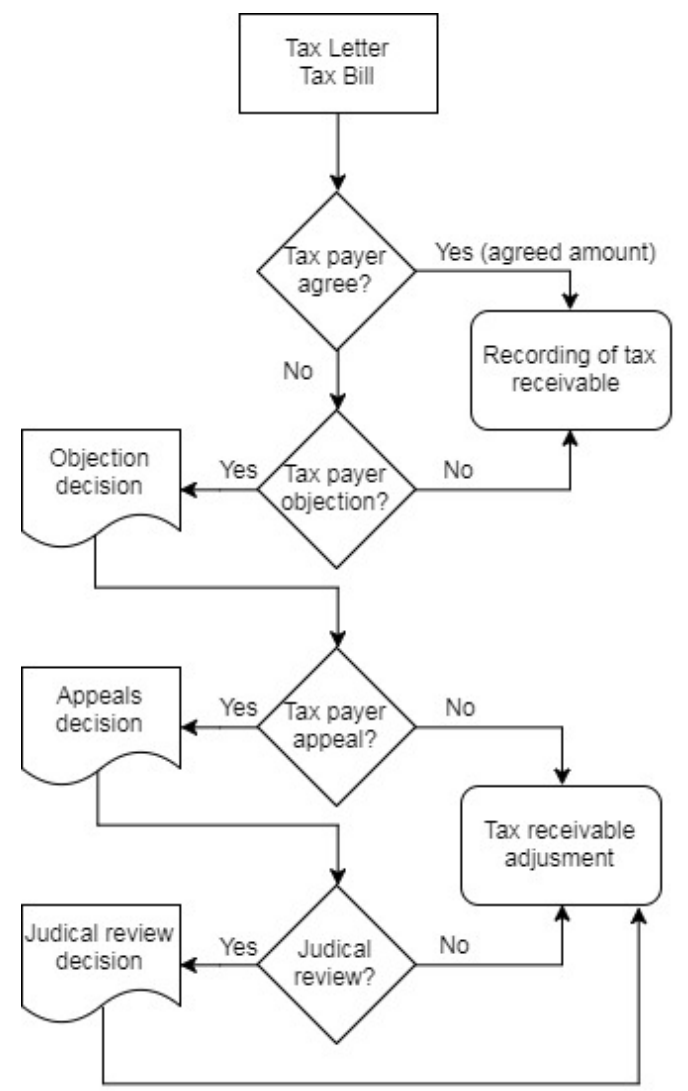

Risks and Control

Fig.1.Tax Receivable Recognition Scheme Source: Data Processed

\section{Risks and Control on the establishment of tax receivable balance}

Based on the interview results, the risks related to the establishment of opening balance of tax receivable is relatively small. This case caused by the opening balance is established from the financial report of the previous year audited by BPK.

Risk and Control on the Process of Tax Receivable Determination from Non-Land and Building Tax (NonPBB)

Based on the interview results, the researchers arrange the list of risks faced on the non- PBB tax receivable determination that still has a gap on the control as described in Table 1 . There are 3 risks identified that still has a gap on control as describe in Risk and Control Matrix table, with analysis given as follows.

1) RI. Some Tax Letter aren't input to SIDJP

Related to the completeness assertion, there are risks over tax receivable transaction which are not documented and reported in the financial report. These risks occur because the procedure allows Tax Letter to be 
issued manually. These risks eventually will impact on the tax receivable balance which could be potentially understatement.

Table.1. RCM of Tax Receivable Determination Process through the Issuance of Tax Letter/Tax Bill

\begin{tabular}{|c|c|c|c|c|}
\hline ID & Risk & $\begin{array}{c}\text { Existing } \\
\text { Control }\end{array}$ & $\begin{array}{c}\text { Nature of } \\
\text { control }\end{array}$ & Gap \\
\hline R1 & $\begin{array}{c}\text { There is Tax Letter } \\
\text { which is not input } \\
\text { in SIDJP }\end{array}$ & $\begin{array}{c}\text { Prenumbering } \\
\text { of Tax Letter }\end{array}$ & $\begin{array}{c}\text { Preventive } \\
\text { Control }\end{array}$ & $\mathrm{V}$ \\
\hline R2 & $\begin{array}{c}\text { There is Tax Bill } \\
\text { which is not input } \\
\text { into SIDJP }\end{array}$ & $\begin{array}{c}\text { Billing section } \\
\text { executor } \\
\text { inputs Tax Bill } \\
\text { through } \\
\text { convention } \\
\text { menu }\end{array}$ & $\begin{array}{c}\text { Preventive } \\
\text { Control }\end{array}$ & $\mathrm{v}$ \\
\hline R3 & $\begin{array}{c}\text { Tax Bill doesn't } \\
\text { publish }\end{array}$ & Not exist & $\mathrm{X}$ & $\mathrm{V}$ \\
\hline
\end{tabular}

Source: Interview result processed

2) R2. There are Tax Bills Un-Input Into the SIDJP

The calculation note of Tax Bill collecting interest is input into the SIDJP by collecting section and then printed in the billing section. The risks might appear in this process are the un-input Tax Bill into the SIDJP because the Tax Bill collects interest issued manually. If the risks happen, it will cause the presentation of tax receivable in the financial report of DGT become understatement.

3) R3. Un-Issued Tax Bill

The overdue of input objection decision by DGT's regional office in SIDJP causes the overdue of the calculation of penalty. Hence, the issue of Tax Bill is overdue. Similarly, the objection decision is issued manually by tax courts. The overdue of the source document reception which becomes the basis of Tax Bill issuance, causes the Tax Bill to become un-issued/issued overdue. If the risks happen, the assertion completeness is not fulfilled.

Risks and Control on Tax Receivable Adjustment Process from the Result of Legal Action

Based on the interview with the interviewees, the process of receivable recognition has some risks as describe in Risk and Control Matrix table below.

Table.2. RCM on the Process of Tax Receivable Adjustment

\begin{tabular}{|c|c|c|c|c|}
\hline ID & Risk & Existing Control & $\begin{array}{c}\text { Nature of } \\
\text { control }\end{array}$ & Gap \\
\hline R4 & $\begin{array}{l}\text { Tax payer's } \\
\text { objection } \\
\text { decisions aren't } \\
\text { input in the } \\
\text { SIDJP }\end{array}$ & $\begin{array}{l}\text { the Head of } \\
\text { Objection and } \\
\text { Appeal Section } \\
\text { executes } \\
\text { checking }\end{array}$ & $\begin{array}{c}\text { Detective } \\
\text { Control }\end{array}$ & $\mathrm{V}$ \\
\hline R5 & $\begin{array}{l}\text { The result of } \\
\text { appeal is not } \\
\text { input timely }\end{array}$ & Not exist & $\mathrm{X}$ & $\mathrm{v}$ \\
\hline R6 & $\begin{array}{l}\text { The result of } \\
\text { appeal which is } \\
\text { not input doesn't } \\
\text { change the } \\
\text { balance of tax } \\
\text { receivable }\end{array}$ & Not exist & $\mathrm{X}$ & $\mathrm{V}$ \\
\hline
\end{tabular}

Source: Interview result processed

1) R4. Un-input Tax Payer's Objection Decision to SIDJP

The objection decree data is input through 3 ways; they are case management, a conversion menu which can be done by 2 modules; objection and appeal administration module and updating of billing section; and number taking. However, there has not been any convincing control that all objection decrees produced manually have been input via conversion menu by the objection analyzer in DGT regional office.

2) R5. Appeals Decision Is Not Input Timely

The appeals decision from the tax court becomes the DGT's basis for determining the amount of the tax receivable which has to be paid by the tax payer. The risk related to this process is that the appeals decree is not accepted or overdue accepted by DGT. This risk occurs because there has not been an integrated information system between DGT and tax court. This causes the recording or receivable become inaccurate, and receivable balanced becomes misstated. 
3) R6. Objection Decision Input Doesn't Change the Balance of Tax Receivable

The objection proposal not input to the objection menu. Hence, SIDJP will recognize it as a tax receivable by the time of inkracht, although the objection process is still running in DGT regional office. Reviewing process of the objection application is still conducted because it is still run manually based on the source of physical document conveyed by the tax payer. This error made the objection decree issued by DGT regional office will not impact on the tax receivable amount.

\section{Risks and Control on the Process of Tax Receivable Completion}

The risks identified from the process of tax receivable completion that still has a gap on control is listed on Risk and Control Matrix below.

Table.3. RCM on Process Tax Receivable Completion

\begin{tabular}{|c|c|c|c|c|}
\hline ID & Risk & Existing Control & $\begin{array}{c}\text { Nature of } \\
\text { control }\end{array}$ & Gap \\
\hline R7 & $\begin{array}{c}\text { Calculation of } \\
\text { overpayment } \\
\text { in the tax } \\
\text { receivable } \\
\text { payment }\end{array}$ & Not Exist & $\mathrm{X}$ & $\mathrm{V}$ \\
\hline
\end{tabular}

Source: Interview result processed

1) R7. Calculation of overpayment in the tax receivable payment

Tax payer should pay off the amount he has agreed upon before proposes a legal action. Based on taxes act, the tax payer will be charged administration fine of $50 \%$ from the tax amount that is obliged to be paid, if the objection application is rejected or granted partially. To avoid the fine, the tax payer could pay more than the amount he agrees (overpayment). Because no accounting policy underlies the recognition of the overpayment, DGT recognizes it as income tax. With consideration that tax value is not agreed by the tax payer, could not be recognized as tax receivable, the balance of tax receivable in each tax payer becomes negative because the recognized amount as receivable is less than the tax amount paid by the tax payer.

\section{CONCLUSION}

Control design in the tax receivable recording has not been completely effective. There are risks identified and deficiency in the control that lead to the potential of misstatement. From the analysis done, the risks might occur from the conditions below.

1. PER-08/PJ/2009 is not suitable with the accrual based rules related to the tax receivable recognition. Tax receivable recognition influenced by the activities of tax billing.

2. Tax Letter and Tax Bill documents can be issued manually. The procedure of the documents issuance is manually issued in force majeure condition as stated in Circular Letter No. SE-91/PJ/2010. There has not been a control executed to ensure the employees issuing the documents manually have done the input via conversion menu.

3. The overdue of judgment and appeals documents acceptance issued by tax court. This is caused by the application as the portal of data exchange between DGT and tax court is not yet available.

To fix the current control design, an improvement on the cause of gaps occurrence is needed. Based on the analysis of the cause of gaps in ICFR design tax receivable described above, the researchers give some recommendations below.

1. Conducting revision on PER-08/P/2009 concerning Guidelines of Tax Receivable Accounting, so that the receivable recognition set can meet the accrual principle.

2. Developing a synchronized feature to accommodate the Tax Letter and Tax Bill document issuance when the SIDJP is offline. Hence, manual issuance is no longer needed.

3. Developing an application which functions as a portal data exchange between DGT and tax court, so that the data exchange related to the tax payer's legal actions can be updated real time.

\section{REFERENCE}

[1] R. R. Moeller. Brink's Modern Internal Auditing, A Common Body of Knowledge. Seventh Edition. John Wiley \& Sons, Inc., (2009).

[2] Government Accounting Standard Board. Government Accounting Standard 01 concerning Presentation of Financial Reporting, (2010).

[3] Government Accounting Standard Board. Technical Bulletin of Government Accounting Standards No. 16 on Accounting of Accounts Receivable Based on Accruals, (2010).

[4] IPSASB. International Public Sector Accounting Standard No 23 on Revenue from Non-Exchange Transaction (taxes and transfer). 
[5] COSO. Internal Control Integrated Framework: Executive Summary, Durham, North Carolina, (2013).

[6] S. Wahyuni. Qualitative Research Method Theory and Practice. Jakarta: Salemba Empat, (2015).

[7] Center for Audit Quality. Guide to Internal Control over Financial Reporting, Washington, D.C., (2013).

[8] Government Accounting Standard Board. Government Accounting Conceptual Framework, (2010).

[9] Directorate General of Taxes. Director General of tax Regulation No. PER-08/P/2009 on Guidelines of Tax Receivable Accounting. (2009). 